\title{
Motivation and difficulties to reduce or quit smoking
}

\author{
Motivação e dificuldades para reduzir ou cessar o uso de tabaco \\ Motivación y dificultades para reducir o abandonar el consumo de tabaco
}

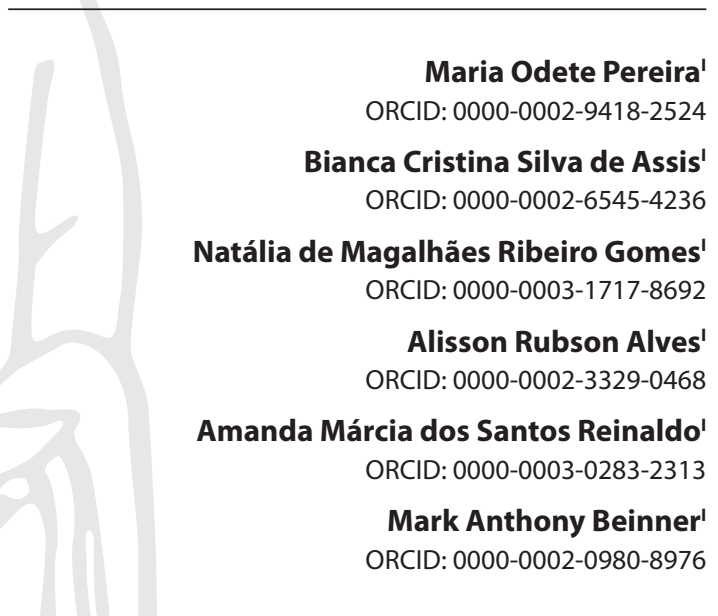

'Universidade Federal de Minas Gerais. Belo Horizonte, Minas Gerais, Brazil.

How to cite this article: Pereira MO, Assis BCS, Gomes NMR, Alves AR, Reinaldo AMS, Beinner MA. Motivation And Difficulties To Reduce Or Quit Smoking. Rev Bras Enferm. 2020;73(1):e20180188. doi: http://dx.doi.org/10.1590/0034-7167-2018-0188

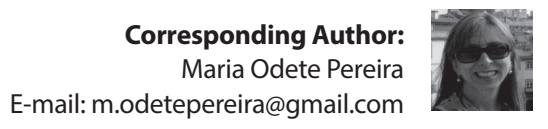

EDITOR IN CHIEF: Antonio José de Almeida Filho ASSOCIATE EDITOR: Fátima Helena Espírito Santo

Submission: $03-29-2018$

Approval: 06-08-2018

\section{ABSTRACT}

Objective: To understand what factors motivate people to reduce or stop tobacco use and what difficulties they face in this process. Method: Qualitative, empirical and interpretative research that used a focal group technique for data collection and Discourse Analysis as a theoretical reference for analysis. Results: The responses centered on the following aspects: motivation for reduction or cessation of smoking, family and community support received during treatment, benefits from cessation of tobacco, difficulties encountered and strategies for overcoming triggers. Final Considerations: The results showed that the users expressed their desire for cessation of tobacco use and that to achieve this goal, family and group support, professional help and changing habits are key factors for this process.

Descriptors: Tobacco Use Disorder; Tobacco Use Cessation; Substance Related Disorders; Psychiatric Nursing; Mental Health.

\section{RESUMO}

Objetivo: Compreender quais fatores motivam as pessoas a reduzirem ou cessarem o uso de tabaco e as dificuldades enfrentadas neste processo. Método: Pesquisa qualitativa, empírica e interpretativa que empregou a técnica de grupo focal para a coleta de dados e a Análise de Discurso como referencial teórico de análise. Resultados: Os discursos versaram acerca dos seguintes aspectos: motivação para redução ou cessação de fumar; apoio familiar e comunitário recebido durante o tratamento; benefícios obtidos com a cessação do tabaco; dificuldades encontradas e as estratégias para vencer os gatilhos. Considerações Finais: Os resultados mostraram que os usuários se expressaram desejosos pela cessação do uso de tabaco e que para alcançar esta meta, o apoio familiar e do grupo, a ajuda profissional e as mudanças de hábitos se revelaram fatores determinantes no processo.

Descritores: Tabagismo; Abandono do Uso de Tabaco; Transtornos Relacionados ao Uso de Substâncias; Enfermagem Psiquiátrica; Saúde Mental.

\section{RESUMEN}

Objetivo: Comprender qué factores motivan a las personas a reducir o abandonar el consumo de tabaco y las dificultades que enfrentan en este proceso. Método: Investigación cualitativa, empírica e interpretativa en la cual se utilizó la técnica del grupo focal para la recolección de datos y el análisis del discurso como referencia teórica para el análisis. Resultados: Los discursos trataron los siguientes aspectos: motivación para reducir o dejar de fumar; apoyo familiar y comunitario recibido durante el tratamiento; beneficios de dejar el tabaco; dificultades encontradas y estrategias para superar los disparadores. Consideraciones finales: Los resultados mostraron que los usuarios expresaron su deseo de dejar de usar el tabaco y que para lograr este objetivo, el apoyo familiar y grupal, la ayuda profesional y los cambios en los hábitos demostraron ser factores determinantes en el proceso.

Descriptores: Tabaquismo; Abandono del Consumo de Tabaco; Trastornos Relacionados con Sustancias; Enfermería Psiquiátrica; Salud Mental. 


\section{INTRODUCTION}

Smoking is the leading cause of preventable deaths and an important factor in the development of Chronic, Noncommunicable Diseases (CNCD). The Ministry of Health emphasizes that there are several health damages due to the use of tobacco products, which has been known to cause several comorbidities such as diabetes mellitus, cancer, respiratory, heart, and renal diseases including depression among others in Brazil ${ }^{(1)}$.

Ever since the Brazilian governmental began promoting smokefree environments, smokers have overburdened the country's social and primary health care systems resulting in an increased social intolerance associated with the habit of smoking. Moreover, illness, due to smoking-related diseases, also leads to a reduction in labor market productivity of smokers ${ }^{(2)}$.

In 2016, the percentage of Brazilian smokers, aged 18 years or over was $10.2 \%$. As a result, the country ranks eighth place in the world of the absolute number of smokers ${ }^{(1)}$.

In the 1980s, the Ministry of Health, in collaboration with the National Cancer Institute (INCA), introduced the National Program to Control Tobacco (PCNT). This program aims to reduce the prevalence of smokers, and consequentially, the morbimortality related to the consumption of tobacco-related products in Brazil. The PCNT adheres to a logical model, in which educational, communication, health care actions, associated with the adoption of legislative and economic measures, are reinforced to prevent the onset of smoking ${ }^{(3)}$.

The Smoking Reduction or Cessation Group - SRCG is a health practice that is based on collective, interaction and dialogue. It is a moment where the user feels free to bring an appeal for which he or she seeks help, in association with an informative, reflective and supportive nature given by health professionals who provide follow-up ${ }^{(4)}$.

The onset of reduction or cessation of tobacco use by the user generates discomfort and difficulties in self-control. Although initially perceived, these symptoms diminish or disappear during the process. By means of reduction or cessation of smoking, users perceive greater rewards in the future, such as preventing the onset disease, the financial saving, premature death from associated causes and self-control in relation to the practice of healthy lifestyles ${ }^{(5)}$.

In Brazil, educational, legislative and economic actions have led to a decrease in the social acceptance of smoking, resulting in an increasing number of people who look to quit smoking, thus demonstrating the importance for prioritizing treatment of users.

Studies have shown that health professional counseling of users who wish to reduce or stop smoking is an important strategy ${ }^{(6)}$. Among the therapeutic approaches available for smoking cessation are pharmacological treatment paired with in-group or individualized behavioral approach, also known as cognitive-behavioral therapy ${ }^{(7)}$.

The objectives of the SRCG group are to identify the difficulties, discuss possibilities and arrive at solutions to factors that make adherence to treatment a challenge. Like care, the groups function as a bilateral process, in which the participants teach and learn collectively ${ }^{(8)}$.

\section{OBJECTIVE}

Understand what motivates people to reduce or stop tobacco use and what difficulties are experienced during this process.

\section{METHOD}

To ensure rigor during this study, the Consolidated Criteria for Qualitative Research Reports (COREQ) was used as a support tool. This is a 32 item checklist to report on interviews and focus groups, which is the most common method used for data collection in qualitative health research. Qualitative studies are often used to study the experiences, the meanings of the disease and to explore potential themes. The application of COREQ is intended to encourage improvement in the quality of reporting of qualitative studies, resulting in better conduct and greater recognition of qualitative research as a scientific effort ${ }^{(9)}$.

\section{Ethical aspects}

The research was approved by the Research Ethics Committee and adhered to the ethical principles according to Resolution $466 / 2012$ of the Brazilian National Health Council.

\section{Theoretical-methodological reference}

The authors followed the methodological reference to the National Program "Quitting Smoking without Mysteries" of the National Cancer Institute - INCA, as well as the Motivational Interview.

The first reference is based on the cognitive-behavioral model, which is a recommended approach for treatment of smokers, the basic premise being to understand that smoking is a learned behavior, triggered and maintained by certain situations and emotions and leads to dependence, due to the psychoactive properties of nicotine.

Therefore, the treatment aims to learn a new behavior by promoting changes in beliefs and deconstructing behavioral linkages to smoking by combining cognitive interventions with behavioral skills training. The treatment also relies on the use of drugs, their role well defined in the tobacco cessation process, which is to minimize the symptoms of nicotine withdrawal syndrome, facilitating the intensive approach of the user ${ }^{(10)}$.

In addition to the "Quit Smoking Without Mysteries" method, the Motivational Interview (MI) was used. MI uses a set of strategies employed to help individuals increase intrinsic motivation by exploring and resolving indecision regarding specific behavior change. The main objective is to assist in the reflexive processes for behavioral changes, striving to resolve this hesitation ${ }^{(11)}$.

\section{Study type}

This was a qualitative, empirical and interpretative research study.

\section{Methodological procedures}

\section{Study Scenario}

The study scenario centered on a group of smokers seen by mental health nurse specialists at the hospital school outpatient services of the Federal University of Minas Gerais (UFMG). 


\section{Data source}

The study population were individuals who participated in the SRCG group at the hospital school outpatient services and who met the following inclusion criteria: minimum age of 18 years, gave their consent to participate in the study upon signing the Informed Consent Term - TCLE and had participated in the smoking maintenance group at least twice. All group enrolled participants were invited via telephone. To maintain the participants' right to privacy, the responses were coded using flower names.

\section{Data Collection and organization}

Data collection was performed using the Focal Group Technique, by obtaining data in group sessions, which were composed adult smokers, participants in the program to reduce and stop smoking ${ }^{(12)}$.

The above data collection technique is based on the participants' reflection and expression about a certain phenomenon, which becomes the center for discussion and exchange of experiences, and in turn, becomes an integral part of the process ${ }^{(13)}$.

The adopted methodology is aligned with Minayo's proposal( ${ }^{(14)}$. The author argues that a focus group should be composed of between six and twelve people and that a moderator and facilitator should be present, their function being to ensure that the debate flows in a participatory manner, that is, all the subjects participate with in-depth form of discussions.

The focal group was performed in two moments, with intervals of fifteen days and a duration of 90 minutes each. The interventions were recorded for later transcription and analysis. This part of the study took place from August to September, 2017.

At the moment of data collection, the on-duty nurse and one of the authors served as group moderators and facilitators. The role of the nurse was to ensure an effective flow of the study presentation by participants, while the other co-author conducted the focus group questions, as well as clarified any doubts concerning the data collection process.

To guide the focus group, participants were presented with questions about the difficulties faced in reducing or terminating tobacco use, family and social network participation during the process, strategies used to overcome the cravings caused by abstinence, and the triggers that trigger them.

\section{Data analysis}

For the analysis of the results, the technique of Discourse Analysis ${ }^{(14)}$ was used, according to the following steps: float reading, data organization, definition of thematic categories, and exploring content.

Data organization resulted in the definition of five thematic categories: what motivated you to abandon tobacco use, when family support is lacking, the value of support in the process of reduction or cessation of tobacco use, focusing on the decision and benefits of quitting smoking, and difficulties and strategies to overcome the triggers.

\section{RESULTS}

According to the sociodemographic results, observed from the 19 participants, aged 47 to 69 years, the largest age group was between 47 to 58 years $(n=10)$; there were more females ( $n=14)$, single $(=7)$; resided in Belo Horizonte $(=17)$, employed $(n=11)$, earning minimum wage $(n=11)$, were home owners ( $=15)$, and stated that they had eleven years of schooling $(n=8)$.

Mean prevalence of tobacco consumption was 14 years and 6 months, with a mean daily consumption of 40 cigarettes, and their mean age was 41 years and 6 months of age.

The oral responses, recorded during the focus group, covered the following aspects: motivation to reduce or stop smoking, family and community support, the benefits of smoking cessation, and the difficulties encountered and strategies for overcoming triggers.

\section{What motivated the abandonment tobacco use}

Appeals by relatives were the primary reasons for cessation of tobacco use. For Camelia, the granddaughter's questions led her to seek help, as the following text shows:

Here my granddaughter, eight years old, came to me and said: Grandma! Why are you smoking? This is bad! This kills! I had no answer for her! (Camelia)

For Rosa, the motivation came from her children, as she revealed in her response:

Actually, what motivated me was my children. They saw that I was smoking too much and complained to me a lot! (Rose)

Dalia considered the idea of abandoning tobacco use on account of the family:

What brought me to this group was my family, because I felt that I needed to stop. They are wonderful people and I was not giving the feedback I should have given them. (Dahlia)

For Margarida, what motivated her to stop smoking were the difficulties with her relations to social interaction at work, as expressed in her response:

At my work, at meeting, sometimes they had someone else replace me, because my clothes smelled like cigarettes. (Sunflower)

\section{When family support is lacking}

Lack of support and distrust by family members were expressed by the participants as factors that hampered the reduction or cessation of smoking.

In this sense, Lily reported the family's concern for changing her habits, but without giving her support:

Because it is a terrible obligation. "Still no? You are going to start smoking! How many days have you not smoked? How long will you continue going to this treatment? Ah! You'll end up going back!" The family has to be together. In my house I have no support! (Lily)

Rosa said she suffered as a result of her sister's distrust:

My sister does not believe me. She thinks I'm smoking at work. She says: "You don 't smoke here at home, but I'm sure that you smoke 
at work. There, there is a kitchen, she goes there and smokes". She does not believe I quit smoking. (Rose)

Other participants reported partial support at home, as revealed in the response by Sunflower:

My family supports me too much. My daughters help and they say: "You have to go and join the group". Only my husband does not believe much. "... you've already had three meetings; you already attended the church and you did not stop. You went back to smoking twice as much". (Sunflower)

\section{The value of support during the process of reducing or quitting smoking}

The support received by the smoking group, as observed from the responses by the participants, was viewed as a key factor for the reduction or cessation of tobacco use. Lily expressed in her response:

I want to quit smoking, but I cannot do it alone. So through the group, the medicine I'm taking and the support, it helps. (Lily)

For Sunflower, her experience was similar:

Because, by myself, I will not be able to, but if I follow up with the group and get the medication, then I can. (Sunflower)

In addition, Dahlia reported:

I think I wouldn't be able to if I was not in this group. (Dahlia)

The support group was considered an incentive tool and a moment to exchange experiences, where the participants could share their difficulties in their effort to stop smoking.

Sunflower reported that the group was an encouraging force:

This group helps a lot to stop smoking. It gives me hope! For me it's very important! I really enjoyed the group. (Sunflower)

For Violet, it is a place to express ones freedom:

Whenever you need me to come to the meeting I come, to all meetings, because it helps a lot to be here. Here we are free to talk to each other, to vent what is happening. For me, quitting smoking alone is difficult. (Violet)

Another form of support that was evident from the participants' responses was the relationship between the nurse-participant during the treatment process, as expressed by Dalia:

What made me stop too, before the medicine, were the nurses. I get so excited! They welcomed us! I said: look! Most of all, I have to stop for the nurses. (Dahlia)

It depends on those who accompany us. The nurses came and hugged us! (Camelia)

The nurses give us all the strength, which you do not have at home, but you have here in this group. (Lily)

\section{Focusing on the decision and benefits of quitting tobacco use}

The purpose of quitting smoking is very important for success, as Dalia said in her response:

The will exists, the solution lies in the range of sharing the desire to quit smoking, the assertion that I was not born smoking, that I'll stop and I'll make it. (Dahlia)

During the process of reduction or cessation of smoking, participants reported an enhanced quality of life, as Sunflower said:

I felt a lot of breathlessness. The biggest benefit to me is a quality of life. Things I did not do and now I'm doing. (Sunflower)

Dahlia highlighted health-related benefits:

People's lives change too much and change for the better! (Dahlia)

When we smoke, we do not feel anything, we do not even taste it. (Violet)

When we all cry, this desire to cry, it feels like depression. (Lily)

Finally, Bromelia reported a lower perception of fatigue and shortness of breath.

\section{Difficulties and strategies for overcoming triggers}

The associations of daily activities with smoking, together with nicotine abstinence, were evidenced as factors that hampered the process of reducing or quitting tobacco use. Coffee time for Lily was the perfect time to smoke:

The mornings are the most difficult times for me. I already had the habit of getting up and smoking. It's terrible! Instead of drinking coffee, the first thing I was going to do was smoke. (Lily)

Lily also suffered from abstinence:

It is this abstinence, this desire to smoke in the morning, so, with the problems I am going through, I become more fragile. (Lily)

As a strategy to circumvent the habit, Tulip substituted coffee for tea and reported:

I am not drinking coffee in the afternoon. I substituted it for tea, and this is helping me. Sometimes I do not feel like smoking, but when I make the coffee, I end up smoking. (Tulip)

In addition, Tulip began to dedicate her free time to care for her plants.

During the focus group session, Begonia said to colleagues:

Have you noticed that we have been here for almost an hour and nobody has smoked yet? So, it's all in our heads! But for me the difficult thing is solitude: being alone and getting nervous. It all makes me want to smoke. (Begonia) 


\section{DISCUSSION}

In order to understand what motivated the participants in the present study to reduce or stop smoking and what difficulties they faced during this process, the reduction and cessation smoking group was considered an important, fundamental support for quitting smoking.

This modality of support has been evidenced by several studies as a factor that increases the chance of successful cessation for individuals seeking to give up smoking. It involves counseling, discussion and encouragement, as well as activities designed to maximize the motivation to remain abstinent and minimize consumption, improving the skills needed to avoid, and resist the urge to smoke ${ }^{(15)}$.

In a study conducted by Stead et $\mathrm{al}^{(16)}$, the authors reported that support offered by group therapy, individual or telephone counseling, increased the chance of smoking cessation. In addition, when behavioral interventions are combined with pharmacotherapy, there exists greater success rates when compared to non-intervention or when intervention is minimal.

In addition, a one year evaluative, multicenter study of an Intervention Group Program, consisting of eight sessions, in which people were motivated to quit smoking and advised on how to deconstruct the habit and how to avoid relapse, observed a $20 \%$ abstinence rate in the intervention group and a $7 \%$ rate in the control group ${ }^{(17)}$.

The data above were compatible with those of a randomized controlled trial in which interventions that included counseling, education, phone calls, letter sending, and home visits by a nurse, resulted in a $17 \%$ smoking cessation rate ${ }^{(17)}$.

Gorin and Heck ${ }^{(18)}$ observed that the abstinence rate is estimated at $10.9 \%$ when a smoker attempts to quit without external help, against $13.4 \%$ if the user is submitted to a minimum counseling of at least 3 minutes, $16 \%$ for counseling between 3 and 10 minutes, and $22.1 \%$ for counseling for over 10 minutes, demonstrating that intervention groups, led by health professionals, contribute to the reduction or cessation of tobacco use.

In addition to group interventions, Haas et al. ${ }^{(19)}$ demonstrated that proactive interventions, such as community resources for physical activities, educational opportunities and job counseling, were positively associated with tobacco cessation among participants. These findings suggest that attempts to address the broader experiences have proved important in supporting cessation of smoking.

In addition to the support, expressed in the participants' responses, they also highlighted the importance of the established professional-participant relationships during treatment, which has also been shown by Cunha et al. ${ }^{(20)}$, which concluded that the therapeutic relationship is paramount during treatment, and moreover, the professional must be present during the various stages of this process.

According to Rice et. al. ${ }^{(21)}$, the American Nurses Association states that these professionals have great potential to implement interventions for cessation and reduction of tobacco use. In addition, the agency added that nurses should be prepared to help people stop or reduce their use, to avoid first use and to promote strategies to reduce exposure to smoking.
The smoker requires that the professional be available and, in this way, feels motivated to reduce consumption, to self-medicate properly and to attend group sessions and individual consultations. In addition, other forms of contact, such as by telephone or home visits, may help to avoid a relapse ${ }^{(20)}$.

A study by West et al. ${ }^{(15)}$ showed that in the English healthcare services, specialized professionals, that is, trained and working full-time to assist users stop smoking, appeared to be more effective than those who worked part-time. This underscores the importance of careful staffing, training and impact assessment of therapeutic interventions.

In the present study, the responses showed that, among the difficulties in the process of reduction or cessation of tobacco consumption, there are the so-called triggers that detonate the use and withdrawal symptoms. Triggers, understood as a motivational factor to smoking, are difficult to extinguish, since they are prone to relapse. This has also been shown to be correlated with the sociodemographic variables and the degree of psychic dependence on the substance ${ }^{(7)}$.

A similar result was found in a study highlighting the difficulty by tobacco users in coping with nicotine withdrawal symptoms, psychological dependence and behavioral habit associated with smoking, all common barriers to cessation of tobacco use $\mathrm{e}^{(22)}$.

The way the smoker biographically places himself in society can make it difficult to quit smoking, considering the challenges routinely faced in social relations. The user considers the act of smoking a support mechanism for coping with stress resulting from daily activities, including work difficulties and family problems ${ }^{(22-23)}$.

A study published in the Netherlands highlights the socialcultural environment as an important factor in the cessation process. Tobacco users stated that smoking helped them make friends and feel part of a group. However, the participants also reported feeling marginalized in relation to society, due to strict non-smoking policies and restrictions targeting its use in public ${ }^{(24)}$.

Smoking is associated with pleasant and comforting feelings for many smokers. The manifestation of nicotine dependence is associated with physical components such as an intense desire to smoke and, psychological terms, people view tobacco as a companion to deal with moments of stress and frustration ${ }^{(22)}$.

To overcome the difficulties faced in trying to quit smoking, motivation is considered a determinant of success and failure by users during this process. The lower degree of motivation to quit smoking substantiates non-compliance by smokers in therapeutic groups, thus increasing the chance of failure in cessation. Therefore, it is essential to evaluate the smoker's stage of motivation as a means to increase the user's desire to quit altogether ${ }^{(25)}$.

The motivational stage can be understood as how willing an individual is to change ones risk behavior to a lesser risk and preserve ones health. This is divided into five stages. The first, called pre-contemplation, is one in which the individual does not regard his behavior as a problem. In the second stage, contemplation, the smoker recognizes that smoking is a problem and wants to stop ${ }^{(26)}$.

During the third stage, determination, the user is ready and committed to change. The fourth, called action, the individual, 
now committed to stop smoking, seeks therapy as a means of assuring success, increasing self-efficacy and creating external conditions for change. Finally, the maintenance stage is marked by the users continued abstinence from smoking ${ }^{(26)}$.

Relapse to smoking behavior is common. Individuals often cycle through the stages of change several times before reaching stable abstinence. It is important to stress that relapse should not be viewed as a failure, but as an event that may happen and that does not make it impossible for treatment to resume. It should also be viewed as an opportunity for learning for a future attempts at quitting smoking.

\section{Limitations of this study}

Among the limitations of this study were the number of participants, which prevents the generalization of this data. However, we believe that studies using other techniques of data collection, in addition to a larger sample of users, our data corroborate with those of similar studies. Studies that investigate the path of tobacco use and cessation or reduction attempts, as well as understanding a user's perception, identifying the difficulties to maintain abstinence and the factors that contributed to relapse should be further explored. It is vital in understanding how this information will contribute to the proposal of actions and the elaboration of safe and effective group intervention strategies for reduction or cessation by smokers.

\section{Study contributions}

This study contributes to our understanding of the difficulties and motivations by group participants to stop smoking and to the negative impact that smoking has on their social, family, professional, and health dimensions.
In addition, the study demonstrated that family support is essential for treatment and non-participation is a risk factor for relapse. It also showed the need to work together on family expectations, verbally expressed, during the moment of relapse, and a loss of credibility by the subject, when this occurs. The study points to a moment as a promoter of anguish and anxiety, which causes demotivation and impairs the maintenance of decision making.

This research revealed the potential of nurses to manage group activities, especially in health promotion and disease prevention of groups. This is a field where the nurse emerges as a professional working from the perspective of health promotion, education and injury prevention. Further studies outlining the potential of nurses' work in this area can contribute toward delineating the state of the art of this subject.

Finally, the study identified teamwork as an important tool in assisting cessation or reduction of smoking treatment.

\section{FINAL CONSIDERATIONS}

The results showed that users expressed their desire to quit smoking, and to achieve this goal, family and group support, professional help and behavioral change have proved to be key factors during this process.

In addition, it was shown that the motivation to quit smoking was associated with family pressure, an extrinsic motivational factor, besides the expressive social difficulty that the habit imposed on them.

\section{FUNDING}

We are grateful to the Research Dean at the Federal University of Minas Gerais (Notice 02/2019) for the financial support to the publication of this manuscript.

\section{REFERENCES}

1. Instituto Nacional de Câncer (INCA). Número de fumantes no país diminui nos últimos 25 anos. Brasília: INCA; 2017.

2. Veloso NS, Rodrigues CAQ, Leite MTS, Ottoni JLM, Veloso GCC, Rodrigues RM, et al. Tabagismo: a percepção dos fumantes em um grupo de educação em saúde. Rev Bras Med Fam Comunidade. 2011;6(20):193-8. doi: 10.5712/rbmfc6(20)216

3. Instituto Nacional de Câncer (INCA). Organização Pan-Americana da Saúde (OPAS). Pesquisa especial de tabagismo - PETab: Relatório Brasil [Internet]. Rio de Janeiro: INCA, OPAS; 2011 [cited 2018 Mar 27]. Available from: http://bvsms.saude.gov.br/bvs/publicacoes/pesquisa_ especial_tabagismo_petab.pdf

4. Santos FB, Bastos AC, Ferreira FF, Matos FSLB, Campos ICC, Freire LM, et al. Implantação do Grupo de Tabagismo na UBS Francelinos no Município de Juatuba-MG. Sinapse Múltipla [Internet]. 2017 [cited 2018 Mar 28];6(2):195-8. Available from: http://periodicos.pucminas.br/ index.php/sinapsemultipla/article/viewFile/16494/12684

5. Mesquita AA. Avaliação de um programa de tratamento do tabagismo. Rev Bras Ter Comport Cogn [Internet]. 2013 [cited 2018 Mar 27];15(2):35-44. Available from: http://pepsic.bvsalud.org/scielo.php?script=sci_arttext\&pid=S1517-55452013000200004

6. Prochaska JJ. Failure to treat tobacco use in mental health and addiction treatment settings: a form of harm reduction? Drug Alcohol Depend. 2010;110(3):177-82. doi: 10.1016/j.drugalcdep.2010.03.002

7. França SAS, Neves ALF, Souza TAS, Martins NCN, Carneiro SR, Sarges ESNF, et al. Factors associated with smoking cessation. Rev Saúde Pública. 2015;49:10. doi: 10.1590/S0034-8910.2015049004946

8. Figueiró LR, Barros HMT, Ferigolo M, Dantas DCM. Assessment of factors related to smokers' adherence to a short-term support group for smoking cessation: a longitudinal study in a developing country. Trends Psychiatry Psychother. 2017;39(1):19-28. doi: 10.1590/2237-6089-2016-0041

9. Tong A, Sainsbury P, Craig J. Consolidated criteria for reporting qualitative research (COREQ): a 32-item checklist for interviews and focus 
groups. Int J Qual Health Care. 2007;19(6):349-57. doi: 10.1093/intqhc/mzm042

10. Instituto Nacional de Câncer (INCA). Deixando de fumar sem mistérios: entender por que se fuma e como isso afeta a saúde [Internet]. Rio de Janeiro: INCA; 2004 [cited 2018 Mar 29]. Available from: http://bvsms.saude.gov.br/bvs/publicacoes/manual_pare_de_fumar_01.pdf

11. Rollnick S, Miller WR, Butler CC. Entrevista Motivacional no cuidado da saúde: ajudando pacientes a mudar o comportamento. Porto Alegre: Artmed; 2009.

12. Dickinson DM, Johnson SE, Coleman BN, Tworek C, Tessman GK, Alexander J. Nicotine Tob Res. 2016;18(5):850-6. doi: 10.1093/ntr/ntv285

13. Kinalski DDF, Paula CC, Padoin SMM, Neves ET, Kleinubing RE, Cortes LF. Focus group on qualitative research: experience report. Rev Bras Enferm [Internet]. 2017;70(2):424-9. doi: 10.1590/0034-7167-2016-0091

14. Minayo MCS. O desafio do conhecimento: pesquisa qualitativa em saúde. 14a ed. São Paulo: Hucitec; 2014.

15. West R, Raw M, McNeill A, Stead L, Aveyard P, Bitton J, et al. Health-care interventions to promote and assist tobacco cessation: a review of efficacy, effectiveness and affordability for use in national guideline development. Addiction. 2015;110(9):1388-403. doi: 10.1111/add.12998

16. Stead LF, Koilpillai P, Fanshawe TR, Lancaster T. Combined pharmacotherapy and behavioural interventions for smoking cessation. Cochrane Database Syst Rev. 2012 Oct 17;10:CD008286. doi: 10.1002/14651858.CD008286.pub2

17. Pérez-Tortosa S, Roig LC, Manresa JM, Martin-Cantera C, Puigdoménech E, Roura P, et al. Continued smoking abstinence in diabetic patients in primary care: a cluster randomized controlled multicenter study. Nicotine Tob Res. 2014;16(11):1417-28. doi: 10.1016/j. diabres.2014.09.009

18. Gorin SS, Heck JE. Meta-analysis of the efficacy tobacco counseling by health care providers. Cancer Epidemiol Biomakers Prev [Internet]. 2012 [cited 2018 Mar 27];13(12):2012-22. Available from: http://cebp.aacrjournals.org/content/13/12/2012.full-text.pdf

19. Haas JS, Linder JA, Park ER, Gonzalez I, Rigotti NA, Klinger LV et al. Proactive tobacco cessation outreach to smokers of low socioeconomic status: a randomized clinical trial. JAMA Intern Med. 2015;175(2):218-26. doi: 10.1001/jamainternmed.2014.6674

20. Cunha SSFP, Batista MH, Melo AKS, Silva RM, Brasil CCP. Os significados do tratamento antitabagismo com intervenções complementares na visão dos tabagistas [Internet]. In: Anais do $6^{\circ}$ Congresso Ibero Americano Investigação Qualitativa em Saúde (CIAIQ), 2017 July $12-14$. Salamanca; 2017 [cited 2018 Mar 27]. Available from: http://proceedings.ciaiq.org/index.php/ciaiq2017/article/view/1612/1566

21. Rice VH, Heath L, Livingstone-Banks J, Hartmann-Boyce J. Nursing interventions for smoking cessation. Cochrane Database Syst Rev. 2017;12:CD001188. doi: 10.1002/14651858.CD001188.pub5

22. Jesus MCP, Silva MH, Cordeiro SM, Korchmar E, Zampier VSB, Merighi MAB. Understanding unsuccessful attempts to quit smoking: a social phenomenology approach. Rev Esc Enferm USP. 2016;50(1):71-8. doi: 10.1590/S0080-623420160000100010

23. Yang JJ, Song M, Yoon HS, Lee HW, Lee Y, Lee SA, et al. What are the major determinants in the success of smoking cessation: results from the health examinees study. PLoS One. 2015;10(12):e0143303. doi: 10.1371/journal.pone.0143303

24. Bommelé J, Schoenmakers TM, Kleinjan M, van Straaten B, Wits E, Snelleman M, et al. Perceived pros and cons of smoking and quitting in hard-core smokers: a focus group study. BMC Public Health. 2014;14:175. doi: 10.1186/1471-2458-14-175

25. Pawlina MMC, Rondina RC, Espinosa MM, Botelho C. Ansiedade e baixo nível motivacional associados ao fracasso na cessação do tabagismo. J Bras Psiquiatr. 2014;63(2):113-20. doi: 10.1590/0047-2085000000014

26. Félix Júnior IJ, Calheiros PRV. Motivation for change among drug users and justice: a literature review. Rev Psicol Teor Prát. $2017 ; 19(2): 73-85$. doi: 10.5935/1980-6906/psicologia.v19n2p73-85 